\title{
The Prophet between Doctrine, Literature and Arts: Introduction to Volume I
}

\author{
Denis Gril, Stefan Reichmuth and Dilek Sarmis
}

The Muslims' relationship with the Prophet Muhammad, as reflected in their daily lives, in devotional practice, in scholarly, legal and political activities and in literary and artistic expression, largely derives from a rich doctrinal and cultural heritage that was shaped over the centuries by diverse societal and regional contexts. Approaching this relationship therefore requires taking full account of the plurality of, and sometimes competition between, different representations of the Prophetic figure, and of the changing modalities of Prophetic piety over the course of Islamic history.

The first volume in the series is devoted to the figure of the Prophet as it was established and transformed since the beginnings of Islam, then throughout the Middle Ages and in modern times, up to the turn of the twentieth century. This volume aims to show that doctrinal representations of the Prophet are inseparable from those prevailing in literature, music and the visual arts, and that both doctrinal and aesthetic images of him have existed in a state of constant interaction. Along with the general focus of the French-German project on the Prophet in the mirror of his community in the early modern and modern periods (see the General Introduction above), this volume also discusses earlier doctrinal, spiritual and literary developments that retained their importance in the development of the image of the Prophet and for Muslim piety in later times. The studies largely go back to two conferences held by the project in 2017 , with some additional contributions which were specially requested. ${ }^{1}$ With its combined attention paid to doctrinal, literary and artistic expressions, the volume will hopefully shed new light on the interactions between the different cultural spheres in Muslim societies, and it will confirm - if need be - the artificial nature of any division between learned and popular religious orientation and practice.

1 Between God and Man: The Representations of the Prophet in the Construction of Islamic Knowledge; Paris, 5-6 July 2017, https://prophet.hypotheses.org/workshop-paris-july-2017; Between God and Man: Representations of the Prophet in Literature, Arts, and Media; Bochum, 9-10 November 2017, https://prophet.hypotheses.org/between-god-and-man-repre sentations-of-the-prophet-in-literature-arts-and-media. 
Without even attempting to be exhaustive, this first volume seeks to underline the diversity of the scholarly, literary and artistic forms of representation of the Prophet in various temporal and cultural contexts and in different parts of the Muslim world, with a clear preponderance of Arabic and Turkic literatures. Some of the contributions concern a specific time and place, while others highlight the maturation of doctrines and the adaptation of topics and genres to novel requirements in a diachronic perspective. The volume thus includes a wide range of representations of the Prophet, from the Qurān and the early magh $\bar{a} z \bar{\imath}$ literature to literary samples and devotional and calligraphic artefacts of the eighteenth and nineteenth centuries, combining in-depth case studies with overview articles. By juxtaposing the development of Sufi orientations towards the Prophet with the place given to him, along with 'Alī b. Abì Taalib in Twelver and Ismāîlī Shīism, and with the very specific views of the Muslim philosophers on prophethood, this book seeks to open up perspectives on the cross-connections between multiple attitudes towards the figure of the Prophet. The literary and artistic expressions of veneration and love for the Prophet which have been gathered here, might likewise offer a promising field for further comparative research on the actualisation of his presence in different cultural, medial and linguistic settings in the course of Muslim history.

The volume's five sections begin with a focus on the representations of the Prophet in Qurān, hadīth and sìra/maghāzì literature and their cultural embedding in Muslim societies (Part 1). This is followed by a closer look at the developments leading towards a theology of veneration of the Prophet in Sunnī Islam (Part 2). The images and functions of the Prophet in Shīi doctrine and in Islamic philosophy are then presented in a comparative perspective (Part 3). The two concluding sections discuss the poetic exaltation of the Prophet across different Islamic literatures (Part 4), and the strikingly common characteristics of his aesthetic representation in literary, scriptural and pictorial imagery (Part 5 ).

This structural and thematic approach made it impossible to bring all the contributions into a strictly diachronic arrangement, which would show an undeniable progression and deepening of scholarly and devotional prophetology and an increasing personal attachment to his person. Nevertheless, within each section, a certain chronological order has been observed to illustrate such a development as closely as possible. Along with its thematic perspectives, the book thus documents an observable historical process, albeit one that appears to have been far from continuous. There was no shortage of reactions to manifestations of devotion deemed excessive over the centuries; reactions which, however, have followed their own Prophet-centred agenda and have only belatedly reversed a pious trend that had been largely driven by Sufism 
over centuries. In many respects such anti-Sufi prophetologies can be seen as belonging to the same trend towards a Prophet-centred piety that they otherwise detested. It is in the second volume, devoted more specifically to the early modern and contemporary periods, that these controversies are more fully discussed. ${ }^{2}$

In general terms, this first volume attempts to reflect some of the early developments of Islamic prophetology and devotion and their fanning out into different fields of doctrinal, literary and artistic expression. With the Qur'ān and the early maghāzi literature as points of departure, the underlying historiographical framework first touches the period between the eleventh and thirteenth centuries. It can be considered as formative both for the emergence of a prophetological doctrine encompassing elements of figh, kaläm and Sufism, and for a turn in Sufism itself which attempted to explore and imitate the "inner states" ( $a h w \bar{a} l)$ of the Prophet for its journey towards God. This is also the period when the concept of the "Reality" (haqiqa) of the Prophet as a metaphysical and cosmogonic principle gained its strength and maturity. ${ }^{3}$ Quite significantly, the celebrations of the Prophet's birthday (mawlid al-nabī) were also established during that period, first by the Fatimid rulers of Egypt in the eleventh century and then, in a different way, by Sunnī rulers. ${ }^{4}$ Such an interplay between the different Sunnī and Shīì doctrinal and devotional traditions also made itself felt in prophetological thought in later times with the adaption of Sunnī theosophical ideas by Shīi theologians and philosophers. ${ }^{5}$

The next focus is on the period between the thirteenth and sixteenth centuries, with its flourishing culture of hadith transmission and scholarship, its unprecedented abundance of literary expressions of Prophetic praise and devotion, and the emergence and flourishing of pictorial representations of the Prophet. ${ }^{6}$ A time which equally saw the transformation of the Khașāiss $a l$-nabi literature from a legal to a devotional literary genre.

The last period covered by this volume includes studies related to authors and devotional and artistic developments from the seventeenth to the nineteenth (and in one case twentieth) century, with a focus on the Ottoman realm and on Morocco. Veritable cultures of Prophetic piety can be identified for both Ottoman and Moroccan societies during these times, which

2 Heirs of the Prophet: Authority and Power in Early Modern and Contemporary Islam, edited by Rachida Chih, David Jordan, and Stefan Reichmuth.

3 See for this in particular Chodkiewicz, Le Sceau des saints, 134-50.

4 Kaptein, Muhammad's Birthday Festival; Holmes Katz, Birth of the Prophet Muhammad.

5 See for this e.g. Knysh, Sufism: a New History, 36-44, 106ff.

6 Hazan, Le prophète Muhammad; Khalidi, Images of Muhammad; Gruber, The Praiseworthy One. 
are documented here by Sufi writings, by the literary genre of the Ottoman miranciye, in the pious and artistic uses of the hilye (i.e. the description of the Prophet's appearance and character) in Ottoman lands, and in Moroccan calligraphic art. ${ }^{7}$ Scholarship on the Biography (sira) of the Prophet can be found taking on an encyclopaedic outlook, reacting, so it seems, to increasing criticism of the Muslim pious traditions and practices. At the same time, devotion to the Prophet seems to have become a remarkable catalyst for both literary and artistic activities in this period.

The rather selective thematic profile of our volume can only provide some explorative perspectives on a general chronological framework for the history of Islamic prophetology and Prophetic piety. Such a framework remains to be fully worked out; for the first Islamic centuries as well as for the early modern and modern periods until the present.

\section{Part 1. Images of the Prophet in Qur'àn, hadīth, and sīra/maghāzī, and Their Cultural Embedding}

The first part of the book opens with studies on the image of the Prophet as presented in the Qurān and in other early foundational texts of Islam and of Islamic historiography, which highlight the tension between the ordinary human nature of the Prophet, and his universal mission and authority over the destiny of mankind. At the same time, it attempts to trace the embedding of this image and the negotiation and transmission of the Prophetic tradition in Muslim cultural life in different historical contexts.

While the usefulness of the Qurān as a source for a historical biography of Muhammad has been questioned, it nevertheless has much to say about the Prophet, sometimes touching on highly personal matters. Without going into the current controversies about the beginnings of the Qurānic text and its early development, we can nevertheless note that the Quraan, in its final form as a textus receptus, seems to contain, both explicitly and allusively, many of the themes that are discussed in the three volumes of our series. As Denis Gril shows in The Prophet in the Qur'ann: An attempt at synthesis, the mentioned tension between the human nature of the Prophet and the superhuman aspects of his mission pervades the whole book. His Lord sometimes treats him severely, reminding him of his powerlessness and of his election. It is because he is a humble servant of God that he has been distinguished to receive the revelation and to be taken away to see "some of Our signs" (Q 17:1) and has become

7 This could certainly be further documented for other regions like Central and South Asia. 
"a beautiful model" (Q 33:21) for his followers. The Qur'ān establishes a certain form of identification between the Prophet and the other prophets, a mirror effect which in the tradition will turn into an outspoken superiority, particularly with regard to the mir rāj. On the other hand, the text very clearly enjoins believers to devote full obedience and profound veneration to the Prophet. It therefore forms the basis for much of what our research seeks to bring out in the writings, practices and experiences of Muslims.

If the Qurân emphasises above all the mercy of the Prophet, it nevertheless sometimes also shows him as a leader and combatant in an uninterrupted chain of military expeditions, a role in which he is found in the sira throughout the Medina period. Adrien de Jarmy argues that the emergence and development of the maghāzi literature describing the battles of the Prophet and his successors enhanced this representation as a war leader. He observes that this coincided with the transition period between the Umayyad and Abbasid regimes, which saw increased pressure on the borders of the empire (Dating the Emergence of the Warrior-Prophet Character in the Maghāzi Literature (Second/Eighth - Fourth/Tenth Century). In this context of a revived jihäd against external enemies, the refocusing of the Islamic narrative on the figure of the Prophet as a fighter in defence of his community and a guarantor of its cohesion, the nascent maghāzi and sira literature became part of a general trend that can also be identified in early jurisprudence.

The transmission of Prophetic Traditions remained of major importance for Muslim scholarship and religious life long after the establishment of the canonical collections of hadith. The dynamics of this persisting institutional as well as extra-institutional transmission after these collections has remained a rather neglected theme in Islamology. ${ }^{8}$ Caterina Bori offers an illustration of this open-ended process in Hadith culture and Ibn Taymiyya's controversial legacy in fifteenth century Damascus: Ibn Nāșir al-dīn al-Dimashqī and his al-Radd al-wäfir. She recalls the whole "culture of hadith" that can be observed since the Ayyubid period in Damascus, and that created a community of hadith transmitters and scholars who by their isnād links strove to remain in a lasting connection with the Prophet. As in the case of Nāṣir al-Dīn al-Dimashqī (d. 842/1438), director at the Madrasa Ashrafiyya, a leading institution for the teaching of hadith in Damascus, and his defence of Ibn Taymiyya, this community was

8 See for this e.g., Davidson, "Carrying on the Tradition". With view to the persistent search for sound Prophetic Traditions outside the canonical collections, and to the controversial discussion of canonised hadith material that has been going on until the present, one could even argue that the canonisation of hadith itself was never fully concluded. 
also seen as maintaining its attachment even to more controversial members. Nāṣir al-Dīn, contemporary and friend of Ibn Ḥajar al-'Asqalānī (d. 852/1449), resolutely defended the mawlid celebrations against Ibn Taymiyya's fierce criticism. At the same time, he could afford to accept the legitimacy of the latter's honorific title of shaykh al-islām, for his valuable contributions to the scholarly and devotional activities of this group of hadith transmitters. As a basis for personal and collective links to the Prophet, hadith could thus play an integrative and conciliatory role within the religious milieu of fifteenth century Damascus.

The sira fulfils a similar but broader function, by telling of the exemplary and incomparable life of the founder of Islam, attempting to satisfy a scholarly as well as a more general readership. It is also a conciliatory role that Catherine Mayeur-Jaouen brings out for the sirra written by the Shaykh Nür al-Dīn al-Halabì (d. 1044/1635) at the beginning of the seventeenth century ("There is matter for Thought". The episode of the Night Journey and the Celestial Ascension in the Sìra halabiyya). Tributary of the earlier siras, in particular those of Ibn Sayyid al-Nās (d. 734/1334) and al-Ṣâliḥī (d. 942/1536), Ḥalabī draws on many other sources. He reworks a rich Mamluk heritage in order to recast it in his own version. The section on the night journey and the heavenly ascension illustrates how the author, a lawyer, theologian and Sufi, seeks to reconcile the different versions of the story, to give a satisfying explanation to its controversial elements and to bring out its spiritual dimensions. From a certain point of view, "the Sïra halabiyya portrays the author as much as the Prophet." But it is no less true that al-Halabì quite successfully responded to the expectations of his audience. The sir $a$ and, through it, the Prophetic figure serve as a mirror for the believers; and the superiority of the Prophet, evident in the story of $i s r \bar{a}$ ' and $m i{ }^{i} \bar{a} j$, radiates upon his entire community.

\section{Part 2. Towards a Theology of Devotion to the Prophet in Sunnī Islam}

The emergence and standardisation of a fully-fledged Islamic prophetology can be regarded as a major theological change in Sunnì Islam, that is attested for the sixth/twelfth century. It went along with a gradual shift from doctrinal to devotional orientation vis-à-vis the image of the Prophet. The history of Sufi teaching and practice already shows this increasing focus on the Prophet and his example since the fourth-fifth/tenth-eleventh centuries, a development that in later times led to the emergence of a Sufi trend that attempted to cultivate an education for a spiritual life in the presence of the Prophet himself. 
Ruggero Vimercati-Sanseverino analyses al-Qāḍī 'Iyāḍ's classical book al-Shifä̀ bi-ta'rīf huqūq al-Mustafā and its comprehensive prophetological synthesis (Theology of veneration of the Prophet Muhammad: Knowledge and love in the Shifā' of al-Qādī 'Tyā (d. 544/1149)). The author, Qādī of Sabta/Ceuta under the late Almoravids, marshals for this several disciplines: hadith, sirra, daläil al-nubuwwa, jurisprudence (figh) and theology (kaläm). By demonstrating the high rank of the Prophet and his status as God's elect among the creatures, he reminds the believers that, according to hadith, the love of the Prophet is a condition of faith and thus becomes a religious duty. Although only God knows the true value ( $q a d r$ ) of His messenger, Qāḍi 'Iyāḍ explains to the Muslims how to find in the Qurān and hadith sufficient reasons for the veneration and love of the Prophet, by referring to his virtues and his excellent character, to his miracles as well as to his promised intercession at the day of judgement. The Shifä’ thus reinforces the Sunnī idea of a community of believers united in the love of the Prophet for attaining happiness in both worlds. Unquestionably, the book has contributed greatly to the rise of a prophetic piety whose modes of diffusion and expression are discussed in this volume.

In his "Special Features of the Prophet" (Khașāiiș nabawiya): From Jurisprudence to Devotion, Michele Petrone outlines the evolution of a literary genre that was extracted from the religious source texts. It elaborated and discussed the legal privileges (khașāis iş) granted to the Prophet to the exclusion of the rest of mankind. This genre was first cultivated in particular by Shāfi'i jurists interested in a clarification of the legal implications of these khașäiș. It later came under the influence of other categories of writings on the Prophet, such as the Sharaf al-Muștafā of Khargūshī (d. 406/1015-6) and the Shifä), and other writings which emphasised the superiority of the Prophet over the rest of mankind. The three works of Suyūțī (d. 911/1505) reflect the different stages and indeed a turning point of this shift from the juridical to the devotional domain, finally focusing on the Prophet's centrality in the whole cosmos and on his spiritual role for mankind. The Sufi influence on the genre, also expressed in poetical contributions like those of 'Â'isha al-Bā'ūniyya (d. 922/1517), further expanded during the Ottoman period, when it came to provide materials for prayer books like those of Ibn 'Azzūum of Kairouan (d. 959/1552).

Which place does the reference to the Prophet occupy among the early spiritual masters of Islam? Based on the biographical material collected in the Hilyat al-awliyā' of Abū Nu'aym al-Ișfahānī (d. 430/1037), Pierre Lory states that, for the early representatives of the movement of renunciation (zuhd) in the first two Islamic centuries, the love of God seems to be exclusive, the Qurān shows the way to Him, and the sunna serves to attain an inner conformity to the teaching of the Prophet. (Modèle prophétique et modèle de sainteté dans le 
soufisme ancien: quelques exemples). Sufism would later deepen the concept of walāya and to develop it into a "friendship with God". Lory identifies a hagiographic vision of walāya as sainthood and sacred heritage, which includes the Companions of the Prophet, the first ascetics and the early Sufi masters. A turning point is marked by the assimilation of the Sufi tradition of Baghdad to that of Khurāsān, as testified by the Luma' of Sarrāj (d. 378/988). Emphasis was now increasingly placed on the imitation $(i t t i b \bar{a})$ of the Prophet and the internalised observance of the prophetic model, including his legal prescripts, his manners $(\bar{a} d \bar{a} b)$ and virtues ( $a k h l \bar{a} q)$, his spiritual states ( $\left.a h{ }^{\prime} w \bar{a} l\right)$, and his insight into the higher realities (haqä $i q$ ). But this did not go as far as in later Sufism, and the early orientation towards the One God Himself was vigorously maintained.

The focus of Sufi instruction on the Prophet gained unprecedented force in the twelfth/eighteenth century in the book of the Fāsī scholar Ahmad b. al-Mubārak al-Lamați (d. 1156/1743) on the teachings of his illiterate master 'Abd al-'Azīz al-Dabbāgh (d. 1132/1719). This is discussed by Jean-Jacques Thibon (L'éducation par 'la lumière de la foi du Prophète' selon le shaykh Abd al-Azīz al-Dabbāgh (m. 1132/1719) d'après le Kitāb al-Ibrīz de Ahmad b. al-Mubärak (m. 1156/1743). Noting, like Pierre Lory, that there is little reference to the Prophet in ancient and classical Sufism, he also mentions the growing institutional expression of the master-disciple relationship along the model of the Prophet and his companions from the twelfth/thirteenth century onwards. He observes that, in al-Lamatî's book, the old centrality of the Sufi master gives way to a direction of the disciple towards a spiritual education leading to the living and transforming presence of the Prophet himself. Spiritual education according to this author and his Sufi master was to be based on the capacity of the disciple to form a direct link to the Prophet. Al-Dabbāgh, the illiterate saint claiming Khadir, the itinerant prophet, as his master is quoted with often highly original guidance and advice, and for his own continuing relationship with the Prophet. From this experience he derived a peculiar concept of Sufi training (tarbiya), supposed to lead the disciple via the master into the immediate presence of the Prophet, who would then occupy his entire mind and horizon. The influence of this book came to be widely felt in the Muslim world. It testifies to a culmination of Prophet-centred mystical doctrine and piety that can be documented for different parts of the Sunnī world between the seventeenth and the early nineteenth centuries. ${ }^{9}$

9 For this see, among others, Meier, "Mystic Path"; and his Tașliya in sufischen Zusammenhängen; also Radtke, "Sufism in the Eighteenth Century"; Reichmuth, "Quest for Sufi Transmissions"; Chih, Sufism in Ottoman Egypt, 84-92. 
In the first two sections, the figure of the Prophet, in its various aspects, is considered from the point of view of the foundational texts and of some of the disciplines of knowledge that directly spring from their interpretation (such as fiqh and kaläm), and with respect to his growing centrality in Sunnì devotional life and in Sufi thought and practice. The third section turns to other doctrinal configurations in Twelver Shī'ism, Ismāîlism, and philosophy, which combined strands of cosmological thought with a salvation history based on reputed hidden knowledge of the Prophet and his descendants (in the case of Shī'ism) or with a general framework of a universal ethical and political order for mankind (in the case of the philosophers).

Whereas in Sunnism a cosmic and esoteric reality of the Prophet took several centuries to be commonly accepted, this dimension appears in Shīism from the very beginning as the foundation of the doctrine of the imamate and the walāya (to be roughly translated in the Shī'i context as "friendship" and "trusteeship"), and its necessary connection with prophethood. The founding narrative of Shīism closely linked the Prophet to his family and descendants, especially to 'Alī and the Imams as trustees of the hidden meaning of the revelation. For all their historical differences, Twelver Shī'ism and Ismāîlism continued to share this relational structure of the doctrine of the Imamate.

Philosophy maintained a special position towards the Prophet and towards Islamic knowledge and doctrine as a whole, as it had to adapt its doctrines, which were derived from Greek and Hellenistic sources, to the Islamic tradition. It may be said that the result was a figure of the Prophetic law-giver and ruler that appeared more functional than personal.

If Sunnism, and Sufism in particular, acknowledge a particular closeness of 'Alī b. Abī Tālib to the Prophet and accept his excellence in virtue and knowledge, this cannot be compared to his place in Shīite doctrine as Muhammad's closest ally and friend (walī) and his designated trustee and inheritor (wași ). His status as "God's Friend" (wali Allāh) is made explicit even in the Shī'ite profession of faith, and Shīī veneration for 'Alī and his descendants, the imams, came to outweigh the respect paid to the Prophet himself. The way in which the relationship between the Prophet and 'Alì is expressed in Twelver Shīism follows to some extent its history and its general intellectual development, as Mathieu Terrier shows in his chapter, The Prophet Muhammad in Imami Shĩ ism: Between History and Metaphysics. The life of the Prophet is inextricably connected with that of 'Alī and his family and descendants, with whom he shares his primordial and luminous reality, and his central role in a salvation history of suffering. But Shī'ism does not neglect the figure of the Prophet, 
whose life prefigured the historical fate of 'Alī, his sons and the other Imams: he predicted their death and died of poison himself. As the founding principle of revelation, he is also connected with them on the metaphysical level, where the imams are regarded as the actualisation of the Prophetic original potentialities. His veneration thus remains inextricably linked to that of the Imams.

Despite its similarity to Imamism, the doctrinal vision of the Ismā'îli authors concerning revelation and prophethood, which is described in the overview presented by Daniel de Smet (The Prophet Muhammad and his Heir Alï: their historical, metahistorical and cosmological roles in Ismã î̀ first and foremost to be shaped by the concept of a sacred and cyclical history. Some of them tended to equate the "Five" (i.e., Muhammad, 'Alī, Fāṭima, Hasan and Husayn) with cosmic principles structuring the universe. Fāțimid ideologues, bent on maintaining the hierarchical precedence of the Prophet, regarded his relationship to 'Alī in analogy to that between male and female, reflecting "pen" (qalam) and "table" (lawh) of the original creation. Later Nizārī authors placed the authority of 'Ali over that of the Prophet. Their doctrine also found expression in a triad consisting of 'Alī, Muhammad and Salmān. 'Alì's esoteric knowledge represented divine authority for them, and he took clear precedence over Muhammad, with Salmān serving as the "Proof" (ḥujja) of the Imams. Nizārī authors expected a future unveiling of the Imam's quasidivine reality and finally the abolition of the Law. Among the Tayyibites, closer to the Fātimid stock, a certain balance was maintained between the Prophet, his Trustee, and the Imams, between their human nature (nāsūt) and their veiled reality in the divine sphere of the universal intellect (termed here $l \bar{a} h \bar{u} t$ ).

The concerns of the Muslim philosophers with respect to the Prophet are summarised by Meryem Sebti in her La dimension éthique et politique de la révélation prophétique chez les falāsifa. It was not the historical or sacred figure of the Prophet which interested them, but rather the question of what it means in philosophical terms to have among men the bearer of a law of divine origin. Al-Kindī saw the Prophet Muhammad as an embodied perfection of intellectual and rhetorical ability, as bringer of a Law that ensured a virtuous life for mankind. Fārābī also considered the ethical and above all the political dimension of the revealed Law. For Avicenna the preservation of the "Virtuous City" depended more explicitly on revelation, and on prophecy as the perfection of the human soul in its theoretical and practical dimensions. The efforts of the philosophers to bring philosophy and religion into harmony found their culmination with Averroes. Perhaps more than his predecessors, he insisted on the need to maintain the teachings of religion for success in this world and for salvation in the other, as well as for the preservation of the community. The Prophet's mission was to bring otherwise unattainable knowledge and laws to 
mankind. For Averroes and for his philosophical predecessors, the role of the Prophet and of religion itself thus seems to have been above all of a practical, ethical and political nature.

\section{Part 4. The Splendour of Words: Exaltation of the Prophet in Islamic Literatures}

The image of the Prophet that was conveyed by the foundational texts of Islam as well as by theology, jurisprudence, Sufism and philosophy, deeply permeated the Muslims' general orientation and beliefs. It shaped sensitivity, heightened hope, nurtured reverence and aroused love for a Prophet who was perceived as close to the believers and to their community at large. The increase in Prophetic piety that can be observed since the sixth-seventh/ twelfth-thirteenth centuries is all the more evident in poetry, belles-lettres and in the arts, as they affected both intellectual and aesthetic sensibilities. The art of letter writing, long elaborated by the chanceries of the Muslim states, came to be used to address even the Prophet himself. The narrative of the Prophet's Ascension (mi rāj $)$, in turn, particularly inspired poets as well as miniaturists. The stylistic wealth and diversity of the poetry in praise of the Prophet, which was taking root in a multitude of different languages, shows the extent to which he had moved to the centre of poetical imagination and virtuosity. This poetry also became a cherished object of musical performance in the art of $s a m \bar{a}$.

The devotional use of the epistolary genre for addressing the Prophet, which enjoyed particular popularity in al-Andalus and in the Maghreb, is described by Nelly Amri in her article on the famous scholar, $a$ dī $b$ and statesman Lisān al-Dīn b. al-Khatị ('I have commissioned her to fly to you on the wings of my ardent desire'. Letter to the Prophet written by Lisān al-Dīn b. al-Khațīb (d. 776/1375) on behalf of the Nașid ruler of Granada). For the Andalusians and North Africans, letters addressed to the Prophet were a means of expressing their longing for the distant holy cities and their love for the Prophet, and of asking him for his help and intercession, as pilgrims otherwise do during their ziyāra to his tomb. Ibn al-Khațīb brought this literary genre to perfection in letters written on behalf of a ruler of Granada, whose realm was increasingly threatened by his Christian neighbours. The request for divine assistance through the mediation of the Prophet was ever more urgent. Recalling the Medinese roots of the Nașrid dynasty (tracing itself back to the Anșār) also serves to enhance their legitimacy. Apart from this political context, the letter conveys a widely shared "Prophetic culture" centred around the holy cities, the life and mission of the Prophet, his virtues and his primordial reality, his support in this world and his 
intercession in the other. It also includes a more personal imagination of an interior ziyāra as a journey of the heart.

Brigitte Foulon adds a study of three further poems in praise of the Prophet written by Ibn al-Khațīb during his stay in Morocco (Les poèmes d'éloge du Prophète de Lisān al-Dìn Ibn al-Khāțīb). She recalls that, after the life of the Prophet, eulogies were rather addressed to members of his Family by poets of Shīite tendency. It was not until the sixth/twelfth centuries, particularly in Andalusia, that poems in praise of the Prophet came to be written again. In the following century, the Burda of Būṣīin (d. around 695/1296) marked the blossoming of this literary genre. Its links to the commemoration of the mawlid gave rise to a derivative branch of its own, the mawlidiyyāt, in which Ibn al-Khațib also distinguished himself, like many poets of his time in Andalusia and Morocco. In the Marinid kingdom, these manifestations of the veneration of the Prophet went along with the growing importance of his descendants, the ashräf or shurafä in the social and political sphere. In these poems the whole art of the panegyrist consists in reorienting the themes of the classic qașida towards the thwarted but sublimated desire to meet the Prophet, finally culminating in his praise and in a plea for his help.

The literature of the stories of the night journey and the celestial ascension of the Prophet, inspired by allusions in the Qurān and by the longer narratives attested in hadith and sirra, constitutes one of the most eloquent testimonies to the cross-cultural veneration of the Prophet. ${ }^{10}$ Marc Toutant demonstrates this in his article on the mirāj in Timurid court literature (Timurid Accounts of Ascension (mi'rāj) in Türkī. One Prophet, Two Models). The choice of Eastern Turkish, and of the Uyghur alphabet in the case of the first text, illustrates the importance attached by the Timurids to their Genghisid origins. The first text, which is abundantly illustrated, closely renders the traditional story with its first-person narrative, and ends with a vivid description of Paradise and Hell, with obvious moral intentions that tie in with the political program of Shāhrūkh (1405-1447). The five mírājiyya poems of Mīr 'Alī Shīr Nawāài (14411501), court poet and chief adviser of the next Timurid ruler Husayn Bayqara (1469-1501) in Herat, pursue an entirely different line. Inspired by the major Persian poets Sanāì (d. 1131) and Niẓāmī Ganjawī (d. early seventh/thirteenth century), the author describes the mirräj as a mystical journey of love (safar-i 'ish q) through the cosmos with its heavens and planets, leading to the vision of God and ending in a "non-place" beyond existence, where all duality has vanished. The dissemination of these two different, but by no means contradictory, 
types of narrative went far beyond the Timurid court, and both seem to have met the expectations of much wider audiences.

Alexandre Papas tracks the remarkable continuity of the Ottoman mirāciyye in verse or prose from the fifteenth century until the final period of the Ottoman Empire (Mi'rāciyye: The Ascension of the Prophet in Ottoman literature from the fifteenth to the twentieth century). These texts are characterised by a relative simplicity of style, which served their didactic scope. The authors, most of them connected with or influenced by Sufism, presented the miräj as a spiritual ascent. Over and again, they return to the questions raised by the Prophet's ascension: did it take place in a dream or awake, in body or in spirit? What was the nature of this encounter and exchange with God? The age-old debates about the reality of the celestial ascension had not been brought to a close and could be re-opened with any new intellectual turn: consequently, the figure of the Prophet remained a contested heritage. The Ottoman mi rāanāme or mirāciyye, often including praise $\left(n a^{c} t\right)$ and descriptions of the Prophet (hilye), did not cease until the end of the Empire to contribute to the renewal of Ottoman literature, exalting the Prophet with poetic musicality, conveying a feeling of celestial harmony and of beatific joy that makes one think of a Mevlevī sema $\bar{a}$. In the last phase during and after the Tanzimmāt, apologetic interests came increasingly to the fore.

Mohamed Thami El Harrak's overview article brings us to contemporary Morocco, heir to a long tradition of religious poetry, song and music, where the Prophet constitutes the axial topic (Présence du Prophète dans l'art du panégyrique (madīh) et de l'audition spirituelle (samāc). Approche thématique). These poems are recited or sung in mosques, zāwiyas, mausoleums or private houses, and during important public or private events. They accompany Muslim life from the cradle to the grave. The repertoire goes back to various periods and regions, from the Near East as well as from al-Andalus and the Maghreb, including classical poetry, Andalusian muwashshah and zajal, and Moroccan dialectal poetry (malhün). The typology of themes - which often go together in a poem - distinguishes mawlidiyyāt (narrating birth and childhood of the Prophet); shamāiliyyāt (evoking his outer appearance and inner qualities); tașliyāt (prayers on the Prophet); mu jizāt (on his miracles); hijäziyyāt (expressing the longing for the visit of his tomb in Medina), and istishfāiyyāt (asking for his intercession). The author furthermore divides the poems into more popular madih (praise) for larger audiences on the one hand, and into Sufi sama $\bar{a}^{c}$ on the other. Sam $\bar{a}^{c}$ is restricted to Sufi circles and much more allusive and exuberant in its language of bacchic (khamriyya) or erotic (ghazal) poetry. The poetic and musical performance evokes and celebrates the beauty (jamāl) of the Prophet and expresses and invites joy (farah) and love (mahabba) for 
his person. This interplay of esthetical perception and religious emotionality might serve as an exemplary case for the cultural embedding of Prophetic praise, with obvious parallels in other Muslim regions and literatures.

\section{Part 5. The Prophet in the Mirror of Verbal, Scriptural and Pictorial Imagery: Aesthetics and Devotional Uses}

Together with its rich poetic imagery, the representation of the Prophet also came to involve visual elements, whether in the form of figurative illustrations enhancing his memory and majesty, of calligraphic compositions evoking his name and description, or in the display of acknowledged relics like his mantle, sandals or footprints which served to conjure his symbolic presence."1 Such visual displays also involved his assimilation to ritual practices that were accepted as Islamic but, at the same time, included patterns that were clearly inherited from earlier religious traditions. Calligraphy and book art also served to enhance the aesthetic effect of texts dedicated to the memory and glory of the Prophet, and the beauty of letters, words and texts might appear as his own beautiful reality, reflected by the heart and hand of the calligrapher. Textual descriptions, calligraphic compositions and painted images were thus merging in the figure of the Prophet, as visual or textual icons in the service of devotional imagination. This interplay of verbal, pictorial and calligraphic iconography can be found as far back as the thirteenth century, when depictions of the Prophet are first attested. The tendency moves from his naturalist depiction to veiling and to further spiritualisation and abstraction, and finally to a notable preponderance of calligraphic and verbal icons and abstract forms and symbols representing Muhammad. ${ }^{12}$ Devotional aesthetics may endow them with the aura of sacred objects, which radiate their blessing and sacralise their surrounding space as well as their owners and visitors.

The reality and image of the Prophet according to the theologian and poet 'Abd al-Ghanīal-Näbulusī (d. 1143/1737), by Samuela Pagani, leads us to a leading Sufi figure of Ottoman Syria in the seventeenth and early eighteenth centuries. 'Abd al-Ghanī al-Nābulusī (d. 1143/1731), representative of the school of Akbarian Sufism and imbued with the mystical poetry of Ibn al-Fārid (d. 632/1235), was a highly prominent Damascene scholar and spiritual master and, at the

\footnotetext{
11 See the overview in Gruber, The Praiseworthy One, $302 \mathrm{f}$.

12 See the introduction to Gruber, Praiseworthy One, 3-33 for an overview of this long-term development. She also notes that the veiling of the face of the Prophet began only with the Safawids in the sixteenth century (p. 20).
} 
same time, one of the most productive poets of his time. Both his Sufi teaching and his poetic oeuvre have the luminous "Muhammadan Reality" (haqiqa muhammadiyya) as their main axis, which can be experienced in dreams or visions in a waking state, linked to the intermediary sphere between the spiritual and material worlds (barzakh), where divine and higher realities take on visible forms. In such visions the Prophet can be perceived in an authentic way, either in his physical appearance as described in hadith (the so-called hilya), or in purely symbolic and imaginary forms. This is where poetry with its rhetorical figures (bad $\bar{\imath}$ ) and images comes in to exalt the "Muhammadan Reality" in the language of love and passion. For Nābulusī, the interior immersion in the presence of the Prophet justifies all forms of devotion and can manifest itself even in Christian imagery, as attested in his own poems. Pagani draws remarkable parallels between his theory of a spiritual and symbolic Muhammadan imagery and the Christian theology of iconic images, as developed in Arabic already by Abū Qurra (d. 830), bishop of Harran, in an Islamic context. ${ }^{13}$ She also refers for this to 'Abd al-Ghanī's substantial intellectual exchange with one of the leading Christian Orthodox bishops and theologians of his time in the Levant.

Christiane Gruber reconstructs a ritual practice involving glass bottles filled with devotional objects and ornaments, among them a calligraphic description of the Prophet, which survive in the Palace Library at Topkapı and elsewhere and which in some cases can be dated to the early nineteenth century (The Prophet as a Sacred Spring: Late Ottoman Hilye Bottles). The gilded hilye panels which were included together with poetic texts represent a highly popular calligraphic icon of the Prophet, based on a famous hadith of 'Alī who describes his appearance and character. In one of the samples, a miniature Qurann is included instead. The bottles, whose scrapped gold dust remains were collected and used for curative procedures, can be related to a whole set of practices consisting in impregnating or even absorbing materia prophetica in order to benefit from its blessing and its prophylactic and healing effects. In Istanbul, the water used to wash his relics like the footprints of the Prophet and his cloak was equally collected and distributed for such uses. Gruber furthermore draws a parallel to the Christian Orthodox icon bottles and to the veneration of sacred fountains (Greek hagiasma, Turkish ayazma) in Istanbul itself, in which Muslims also participate. This shows the common anchoring of such practices in local culture. The bottles also prove that devotion to the

13 On the impact of Christian iconography on the imagery of the Prophet in Ilkhanid painting in the fourteenth century, Gruber, Praiseworthy One, 92ff, $105 \mathrm{ff}, 120$. 
Prophet touched all classes of society, from the Palace of Topkapı to the popular districts of Istanbul.

Along similar lines, Thomas Heinzelmann analyses three life stories and eulogies of the Prophet that were among the most widely read texts in the Ottoman Empire (Visualising the Prophet - Rhetorical and graphic aspects of three Ottoman-Turkish poems (Süleymān Çelebi's Vesīlet en-Necāt, Yazıcıoġlı's Risāle-i Muhammediyye, and Hākāann’s Hilye). Composed in the fifteenth and sixteenth centuries, they were widely copied and distributed, consecrated as pious foundations, and read but also viewed to admire their layout and beautiful calligraphy, which was deemed to be worthy of the beauty of the Prophet. Some unique abstract illustrations symbolising the Prophet and his Companions are also attested. The three books were written by authors of diverse backgrounds, all of them, however, representatives of an Ottoman spiritual book culture centred on the figure of the Prophet. The Risāle-i Muhammediyye was the object of particular veneration. The original, kept at the author's mausoleum in Gelibolu (Gallipoli), was constantly copied. One of these copyists, the famous Sufi scholar Ismā'il Haqqı (m. 1137/1725), was also keen to reproduce, from the original, the drawing of the "Banner of Praise" (liwä' al-hamd), an eschatological symbol of the Prophet's intercession. The manuscripts show that, over the centuries, such images were touched and kissed, and thus used for a physical contact with the Prophet, which was sought for blessing and salvation, testifying to the use of such abstract images as devotional icons.

As indicated above, calligraphy itself could also serve as a medium for identification with the Prophet and for an immersion in his message. The fusion of mystical experience and calligraphic expressivity is brought out for al-Qandūsī (d. 1278/1861), a Sufi herbalist and calligrapher who lived and died in Fes, by Francesco Chiabotti and Hiba Abid (The World of al-Qandūsì (d. 1278/1861). Prophetology and Calligraphy in Morocco (first half of the nineteenth century). Attracted from his Algerian home zäwiya to Fes by the presence of its founder, Moulay Idrīs, Qandūsī earned his life as a drug-seller. He remained dedicated to his ecstatic and visionary experience and to his calligraphic activities that uniquely show the impact of his contemplations. His case is also important for his personal reflections on the all-compassing "Muhammadan Reality", which shaped his personal experience as well as his struggles with the calligraphic form of the letters. His efforts led to the development of a unique and quite spectacular calligraphic style which is now highly appreciated in the Maghreb. Qandūsī saw himself in hidden but close contact with the Prophet and even considered the name Muhammad as the Supreme Name of God. The calligraphic and codicological analysis of his works shows how the design and tracing of the letters, especially for the name Muhammad, combined 
the expressive potentials of the Maghribì script with the inventiveness of the visionary, where the wonders of the eye and the devotion to the Prophet would feed off each other.

Reading the studies in this volume will show how much their themes and findings intertwine and converge, despite their different sources, disciplines and historical and regional contexts. The "theology of veneration", elaborated by the Qādīi 'Iyād, enhanced a reverential attitude of love towards the Prophet, which was interpreted by a great scholar like Ibn al-Khațīb with great brilliance as an heir to the long Andalusian tradition of epistolary eloquence and poetic refinement. Much later, the poetry and metaphysics of the Muhammadan Reality were expressed in a similar language of love passion. The narratives of the mawlid and mi'rāj transmitted by traditionalists, such as Ibn Nāṣir al-Dīn, and arranged and argued later in the Sira halabiyya, fed into the register of the Moroccan singers, just as they inspired the imagination of Timurid and Ottoman poets. Spiritual fulfilment could be expressed in the mir räj model (as in the poems of Nawä'î), in musical performances celebrating the beauty of the Prophet, and in Qandūsì's visionary calligraphy.

As already stated at the beginning, a recurring theme of the volume is the interplay between the human and the divine aspects of the Prophetic Reality. The Qurān constantly recalls the human nature (bashariyya) of the Prophet while alluding to the pristine light which he embodies, and his closeness to God. It thus sacralises his presence. This double face of the Prophetic person, one immediately perceptible, the other more veiled, is encountered at several levels. Ancient Sufism distinguishes between the external and internal aspects of the sunna, complementary but inseparable in the imitation of the Prophet. The distinction between the exterior and the interior (zāhir/bātin) dimensions runs through many contributions. It can be traced as much to these two divine names as to the attitudes toward the Prophet himself, and it might also be reflected in the literary genres and their attunement to their popular or initiated audiences, as in the case of the Timurid miräj texts. Personal predilections of the respective authors also played their role here, as in the case of Ibn al-Khațib's letters to the Prophet or of Halabï's Sira. From this point of view, Shīism, in its ancient spiritual version, and Ismailism occupy a place apart from but consistent with this foundation of Muslim spirituality: the external and internal faces of reality veil and complement each other. In the 
case of Shīism, Muhammad as Prophet was largely identified with the exoteric aspects of the revelation, whereas 'Alī b. Abì Țālib and the Imams became the guardians of its esoteric dimension. In Sunnī spirituality, mediation passes, if not exclusively, at least mainly through the Prophet. But the role of the Shīiss as forerunners of pious emotional and ritual practice related to the Prophet, as in the case of the mawlid celebrations, still remains a matter for further research.

Esoteric vision cannot be separated from more essential functions of the Prophet, such as his intercession at judgement day for all believers. It may be expressed in terms reserved for an elite but nevertheless concerns the whole community when an Ismāîlī author like Mu’ayyad al-Dīn al-Shīrāzì compares the relationship between the Prophet and 'Ali to that of a male-female couple and their position vis-à-vis the believers as that of father and mother. The set of stories that have nourished the Sira literature, especially those of the battles and warlike expeditions, aims at uniting the community in the face of the trials that it has to face. The miräj narratives highlight the superiority of the Prophet over all his peers and magnify his sublime rank above them. Explicitly or implicitly they also affirm the primacy of the Muhammadan community over the earlier ones. The evolution of the khașä ts literature also goes into this direction. In a more subtle way, the author of the Sira halabiyya also intended to unite the community around its Prophet, by discussing and harmonising narrative variants and diversities of interpretation. The Qāḍī Iyāẹ, in promoting "the veneration of the value of the Prophet" pursued a comparable goal which, judging by the success of his Shifä, was largely achieved. Strangely enough, this integrative function of the Prophet for the Muslim community is not much reflected in the sources themselves; with the notable exception of the philosophers (faläsifa), who show themselves to be strongly interested in the ethical and political role of the Prophets as lawgivers for the "Virtuous City", and of the Prophet Muhammad for the Muslim polity.

As indicated above, a major starting point for our collective research was the observation of a general increase of Prophetic piety since the twelfth and thirteenth centuries, which strongly gained in momentum in the early modern period and still persists in different and sometimes diverging forms to this day. This went along with a growing personal and collective focus on the metahistorical reality of the Prophet, which has emerged before in esoteric teaching. In early Sufism up to the eleventh and even the twelfth century, the exclusive love of God blurred the love of the Prophet, which was only later advocated as the major way to God. This trend seems to be undeniable, even if it still requires closer periodisation and contextual embedding. The role of the Kitāb al-Shif $\vec{a}^{\prime}$ as a watershed in this respect becomes clearer now, and its contribution to the 
emergence of a Prophetic model of spirituality in Sunnī Islam, which coincided with the diffusion of the writings of Ghazālī, in the West as elsewhere, should obviously be re-evaluated.

In the blossoming of a "Prophetic culture" in which scholarly literature, Sufism, poetry, arts and devotional practices were intertwined, the period between the fourteenth and sixteenth centuries was crucial, and it was to have a strong impact on the next centuries. The later Ottoman and Moroccan cases, which are discussed in this volume, show a further intensification of the individual commitment to the Prophet in mystical, literary and artistic activities. The studies suggest that personal identification with the Prophet could sometimes go far. At the same time, an expansion and diversification of the devotional patterns of Prophetic piety can be documented, and its expressions clearly increased in fervour. The tendency towards a symbolic and abstract allusion to the Prophet, which evokes his presence and blessing in pictorial as well as in expressive calligraphic forms, has already been highlighted for Ottoman art since the seventeenth century $;{ }^{14}$ it is further confirmed in this volume and can also be extended to Morocco. Even if not discussed here, oral as well as written poetry in praise of the Prophet also greatly increased in a growing number of languages in the early modern period, ${ }^{15}$ a process that continues to the present day and which will be further addressed in Volume Three.

This volume does not deal with the reactions and polemics against the Sufi doctrines of the Muhammadan Reality, and against the devotional practices that went along with them. ${ }^{16}$ These criticisms, which have gained in public acceptance and political virulence in the course of the twentieth century, will be further discussed in the other volumes (especially in Volume Two). In the face of Salafì/Wahhābī "elephants in the room" in so many Muslim states and societies, and also in research on contemporary Islam, the studies gathered here will hopefully help the reader to overcome the prevailing backwardlooking tunnel vision dominated by a search for Salafĩ and "reformist" predecessors of the present state of Muslim culture. ${ }^{17}$ It should have become clear by now that religious and political trends, even "liberal" or "secular" ones, which crystallised since the late nineteenth century in Muslim social and political life, owed as much to the growth of Prophet-centred pious trends as to the

\footnotetext{
14 Gruber, The Praiseworthy one, 269-303.

15 Many samples and quotations from such poetry in different languages can be found in Schimmel, Und Muhammad ist Sein Prophet; Sperl and Shackle (eds.), Qasida Poetry in Islamic Asia \& Africa.

16 See for this e.g. Lewis, Balance of Truth; Knysh, Ibn 'Arabi.

17 For a fierce critique of the prevailing focus on Wahhābism in the historiography of eighteenth- and nineteenth-century Islamic scholarship, see Dallal, Islam without Europe.
} 
active contributions of both Sufis and their adversaries. ${ }^{18}$ The responses of this Prophetic piety to the transformations of the Muslim lifeworlds and polities in early modern and modern times remain a topical and indeed urgent matter for further inquiry. ${ }^{19}$ In any case, the interplay between doctrine, literature and arts, that has been the topic of this volume, clearly shows that Muslim individuals and communities all over the world have continued to reflect and define their own identity in the mirror of the Prophet and his established biography, and in the beauty and grandeur of his celestial experience.

\section{Bibliography}

(The bibliography only covers the titles indicated in the footnotes. For closer bibliographical reference to the different themes, see the contributions to this volume.)

Chih, R. Sufism in Ottoman Egypt: Circulation, Renewal and Authority in the Seventeenth and Eighteenth Centuries, Abingdon, Routledge, 2019.

Chih, R., Mayeur-Jaouen, C. and Seesemann, R., eds. Sufism, Literary Production, and Printing in the Nineteenth Century, Würzburg, Ergon, 2015.

Chodkiewicz, M. Le Sceau des saints. Prophétie et sainteté dans la doctrine d'Ibn Arabî, Paris, Gallimard, 2012.

Dallal, A. S. Islam without Europe: Traditions of Reform in Eighteenth-Century Islamic Thought, Chapel Hill, University of North Carolina Press, 2018.

Davidson, G. "Carrying on the Tradition. An Intellectual and Social History of PostCanonical Hadith Transmission", PhD diss., University of Chicago, 2014.

Gruber, C. The Praiseworthy One: The Prophet Muhammad in Islamic Texts and Images, London and Bloomington, Indiana University Press, 2018.

Gruber, C. and Colby, F., eds. The Prophet's Ascension: Cross-Cultural Encounters with the Islamic Miraj Tales, Bloomington, Indiana University Press, 2010.

Hazan, O. and Lavoie, J. J. Le prophète Muhammad: Entre le mot et l'image, Montreal, Fides, 1997.

Holmes Katz, M. The Birth of the Prophet Muhammad: Devotional Piety in Sunni Islam, London and New York, Routledge, 2007.

Kaptein, N. Muhammad's Birthday Festival, Leiden, Brill, 1993.

18 For a succinct critical overview of the state of the art in this field of research and public opinion, see Mayeur-Jaouen, "À la poursuite de la réforme".

19 See e.g. the volume by Chih, Mayeur-Jaouen, and Seesemann (eds.), Sufism, Literary Production, and Printing in the Nineteenth Century. 
Khalidi, T. Images of Muhammad: The Evolution of Portrayals of the Prophet in Islam across the Centuries, New York, Doubleday, 2009.

Knysh, A. Ibn 'Arabi in the later Islamic Tradition: The Making of a Polemical Image in Islam, Albany, State University of New York Press, 1999.

Knysh, A. Sufism: A New History of Islamic Mysticism, Princeton and Oxford, Princeton University Press, 2017.

Lewis, G. L. The Balance of Truth by Kätib Chelebi. Translated with an Introduction and Notes, London, Allen and Unwin, 1957.

Mayeur-Jaouen, C. “A la poursuite de la réforme'. Renouveaux et débat historiographiques de l'histoire religieuse et intellectuelle de l'islam, XV ${ }^{\mathrm{e}}-\mathrm{XXI}{ }^{\mathrm{e}}$ siècle", Annales. Histoire, Sciences Sociales, 73, 2 (2018), 317-358, https://www.cairn.info/ revue-annales-2018-2-page-317.htm.

Meier, F. "The Mystic Path", in B. Lewis, ed. The World of Islam: Faith, People, Culture, London, Thames and Hudson, 1976, 117-128.

Meier, F. Bemerkungen zur Mohammedverehrung, Teil 2. Die taṣliya in sufischen Zusammenhängen, ed. B. Radtke, Leiden, Brill, 2005.

Radtke, B. "Sufism in the 18th century: An attempt at a Provisional Appraisal", Die Welt des Islams, 36,3 (1996), 326-364.

Reichmuth, S. "The Quest for Sufi Transmissions as Links to the Prophet: Murtaḍa al-Zabīdì (d. 1791) and his Encyclopedic Collections of Sufi salāsil', in I. Weinrich, ed. Performing Religion: Actors, contexts, and texts. Case studies on Islam, Orient Institut Beirut, Ergon Verlag, Würzburg 2016, 75-99.

Schimmel, A. Und Muhammad ist Sein Prophet. Die Verehrung des Propheten in der islamischen Frömmigkeit, Diederichs, Köln, 1981 (English: And Muhammad Is His Messenger: The Veneration of the Prophet in Islamic Piety, North Carolina Press, Chapel Hill, 1985).

Sperl, S. and Shackle, C., eds. Qasida Poetry in Islamic Asia and Africa, 2 vols. Leiden, Brill, 1996. 